\title{
ALIH KODE DAN CAMPUR KODE DALAM KOMUNITAS MAHASISWA PERANTAUAN ACEH DI YOGYAKARTA ${ }^{1}$
}

\author{
Cut Irna Liyana \\ Dosen Tetap Sosiologi, Universitas Teuku Umar \\ Email: cut.irnaliyana88@gmail.com
}

\begin{abstract}
The aims of this study are to describe and explain the form of code switching and code mixing, to identify the factors of code switching and code mix and to identify the purpose and function of code switching and code mixing in the Acehnese students in Yogyakarta. This is descriptive qualitative research by sociolinguistic approach. The method used in this research is observation method and record technique. The data of this research are the speechs of Acehnese students who are studying in Yogyakarta which contains of code switching and code mixing. Data were identified and classified and then analyzed by existing sociolinguistic theory. The results show that: first, the form of code transfer in Acehnese student communication in Yogyakarta includes the switch of code from Acehnese Language to Indonesian and the switch of code from Indonesian to Aceh; second, the form of mixed code in the form of insertion of words, phrases, and clauses; third, the factors of code switching and code mixing are speakers, participants, third speakers, speech mode and discussion topics; fourth, the purpose and function of code switching and code mixing in the Acehnese students are to familiarize the situation, to make a sense of humor, to look prestigious, to respect the other person and to tell the secret.
\end{abstract}

Key words $\quad$ : Code Switching, Code Mixing, Sociolinguistic

1 Tulisan ini telah disampaikan pada Seminar Nasional Linguistik Universitas Gadjah Mada pada tanggal 24-25 Oktober 2017 dengan beberapa pengembangan dan revisi pada bagian pendahuluan dan pembahasan serta penambahan permasalahan dalam pembahasan yaitu fungsi dan tujuan terjadinya alih kode dan campur kode. Tulisan ini juga telah mengalami beberapa modifikasi pada sistematika penulisan yang disesuaikan dengan template jurnal Community. 


\section{PENDAHULUAN}

Keragaman suku di Yogyakarta menjadikan Yogyakarta bagaikan miniaturnya Indonesia. Keragaman suku ini salah satunya disebabkan oleh banyaknya mahasiswa yang datang ke Yogyakarta untuk melanjutkan studinya. Salah satu komunitas mahasiswa yang ada di Yogyakarta adalah mahasiswa perantauan dari Aceh. Mahasiswa perantauan ini tentu saja melakukan interaksi dengan yang lainnya, baik dengan sesama suku Aceh, sesama mahasiswa pendatang, dan penduduk asli.

Dalam hal ini tentu saja dibutuhkan bahasa sebagai alat komunikasi. Penggunaan bahasa yang tepat dan sesuai sangat mempengaruhi interaksi yang dibangun oleh masyarakat tutur. Untuk memperlancar interaksi ini, mahasiswa perantauan Aceh ini menggunakan dua bahasa di kesehariannya yaitu bahasa daerah dan bahasa Indonesia. Fenomena ini disebut sebagai kontak bahasa.

Thomason (2001: 1) berpendapat bahwa kontak bahasa adalah peristiwa penggunaan lebih dari satu bahasa dalam tempat dan waktu yang sama. Penggunaan dua bahasa secara bersamaan ini tentu saja mengakibatkan munculnya kasus-kasus dalam berbahasa. Hal ini sejalan dengan pernyataan Chaer (2006:35) yang menyatakan bahwa bilingualism dan multilingualisme merupakan akibat dari kontak bahasa sebagai kasus yang muncul dalam pemakaiaan bahasa seperti: alih kode, dan campur kode.

Dalam suatu fenomena tutur, terjadinya fenomena kebahasaan tentunya tidak terlepas dari tujuan dan faktor terjadinya fenomena tersebut. Dalam makalah ini, penulis akan mendeskripsikan dan menjelaskan wujud alih kode dan campur kode, faktor-faktor yang menyebabkan terjadinya alih kode dan campur kode serta fungsi dan tujuan terjadinya alih kode dan campur kode pada komunikasi mahasiswa perantauan Aceh di Yogyakarta.

\section{TINJAUAN PUSTAKA}

\section{Alih Kode dan Campur Kode}

Sebelum membahas lebih jauh alih code dan campur kode yang terjadi pada interaksi dalam komunitas mahasiswa perantauan Aceh, penulis terlebih dahulu ingin memaparkan sekilas tentang alih kode dan campur kode.

Alih kode (code switching) adalah peristiwa peralihan dari satu kode ke kode yang lain dalam suatu peristiwa tutur. Misalnya penutur menggunakan bahasa Indonesia beralih menggunakan bahasa daerah atau sebaliknya. alih 
Community: Volume 3, Nomor 2, Oktober 2017

ISSN: 2477-5746

kode merupakan salah satu akibat dari terjadinya kontak bahasa. Alih kode sering ditemukan pada masyarakat multilingual. Dalam masyarakat multilingual sangat jarang ditemukan penutur yang hanya menggunakan satu bahasa saja.

Nababan (1991: 31) menyatakan bahwa konsep alih kode ini mencakup juga kejadian pada waktu kita beralih dari satu ragam bahasa yang satu, misalnya ragam formal ke ragam lain, misalnya peralihan yang terjadi dari ragam formal ke ragam yang santai dikarenakan alasan-alasan tertentu. Kridalaksana (1982: 7) mengemukakan bahwa penggunaan variasi bahasa lain untuk menyesuaikan diri dengan peran atau situasi lain, atau karena adanya partisipasi lain disebut alih kode. Holmes (2001:35) menegaskan bahwa suatu alih kode mencerminkan dimensi jarak sosial, hubungan status, atau tingkat formalitas interaksi para penutur. Dari pendapat tersebut, dapat disimpulkan bahwa alih kode merupakan gejala peralihan pemakaian bahasa karena perubahan peran dan situasi.

Selanjutnya, campur kode (code-mixing) terjadi apabila seorang penutur menggunakan suatu bahasa secara dominan mendukung suatu tuturan disisipi dengan unsur bahasa lainnya. Hal ini biasanya berhubungan dengan karakteristk penutur, seperti latar belakang sosial, tingkat pendidikan, rasa keagamaan. Biasanya ciri menonjolnya berupa kesantaian atau situasi informal. Namun bisa terjadi karena keterbatasan bahasa, ungkapan dalam bahasa tersebut tidak ada padanannya, sehingga ada keterpaksaan menggunakan bahasa lain, walaupun hanya mendukung satu fungsi.

Kridalaksana (1982; 32) memberikan batasan campur kode atau interferensi sebagai penggunaan satuan bahasa dari suatu bahasa ke bahasa lain untuk memperluas gaya bahasa atau ragam bahasa; termasuk di dalamnya pemakaian kata, klausa, idiom, sapaan, dan sebagainya. Nababan (1989:32) menyatakan bahwa suatu keadaan berbahasa menjadi lain bilamana orang mencampurkan dua (atau lebih) bahasa atau ragam bahasa dalam situasi berbahasa yang menuntut percampuran bahasa itu. Tindak bahasa yang demikian disebut campur kode. Campur kode dapat juga dikatakan sebagai alih kode yang berlangsung cepat dalam masyarakat multilinguistik (Holmes, 2001:42).

Campur kode jarang ditemukan dalam situasi formal. Jikapun ditemukan, campur kode tersebut dilakukan secara terpaksa karena dianggap tidak adanya ungkapan atau padanan yang tepat dalam bahasa dasar sehingga perlu digunakan kata atau ungkapan dari bahasa lain. 
Alih kode dan campur kode merupakan dua peristiwa yang sama-sama lazim terjadi dalam masyarakat multilingual dalam menggunakan dua bahasa atau lebih. Namun, jika ingin membedakan kedua hal ini, terdapat perbedaan yang cukup nyata diantara keduanya. Alih kode terjadi pada masing-masing bahasa yang digunakan dan masih memiliki otonomi masing-masing, dilakukan dengan sadar, dan disengaja, karena sebab-sebab tertentu. Sedangkan campur kode adalah sebuah kode utama atau kode dasar yang digunakan memiliki fungsi dan otonomi, sedangkan kode yang lain yang terlibat dalam penggunaan bahasa tersebut hanyalah berupa serpihan saja, tanpa fungsi dan otonomi sebagai sebuah kode.

\section{METODE PENELITIAN}

Jenis penelitian yang digunakan dalam penelitian ini adalah penelitian deskriptif kualitatif yang fokus pada penunjukan makna, deskripsi, penjernihan, dan penempatan data pada konteksnya masing-masing dan sering kali melukiskannya dalam bentuk kata-kata dari pada angka-angka (Mahsun, 2007: 97). Subjek penelitian ini adalah kelompok mahasiswa perantau yang berasal dari Aceh yang menggunakan dua bahasa atau lebih dalam komunikasinya sehari-hari. Data pada penelitian ini adalah penggunaan variasi kode, alih kode dan campur kode pada komunitas mahasiswa perantauan dari Aceh yang berada di Yogyakarta.

Metode pengumpulan data pada penelitian ini menggunakan metode simak dan teknik catat. Mahsun (2007:242) mengemukakan bahwa metode simak merupakan metode yang digunakan dalam penyediaan data dengan cara penyimakan penggunaan bahasa oleh peneliti. Metode ini dapat disejajarkan dengan pengamatan atau observasi. Teknik catat dimaksudkan bahwa peneliti mencatat data-data yang mengandung alih kode dan campur kode. Penelitian diperbolehkan tidak menggunakan teknik rekam apabila peneliti sudah yakin dengan teknik catat, namun tidak berlaku sebaliknya (Mahsun, 2007: 123). Setelah semua data terkumpul secara lengkap, dilakukan analisis data. Analisis data dilakukan sesuai dengan permasalahan yang ada. Mahsun (2007:253) menegaskan bahwa analisis data merupakan upaya yang dilakukan untuk mengklasifikasikan dan mengelompokkan data. Sejalan dengan pernyataan tersebut, dalam penelitian ini dilakukan dua tahapan analisis data. Pertama, dilakukan pengidentifikasian terhadap data, yaitu mengidentifikasikan bentukbentuk alih kode dan campur kode yang terjadi. Kedua, dari hasil identifikasi tersebut dilakukan pemilahan untuk membuat klasifikasi data. 


\section{TEMUAN DAN PEMBAHASAN}

\section{Alih Kode dan Campur Kode dalam Komunitas Mahasiswa Perantauan Aceh}

Peristiwa pergantian bahasa yang digunakan dari suatu bahasa ke bahasa lain atau berubahnya suatu ragam menjadi ragam lainnya disebut peristiwa alih kode di dalam sosiolinguistik. Appel di dalam Chaer (2010: 107) mendefinisikan alih kode sebagai gejala peralihan pemakaian bahasa karena berubahnya situasi. Berbeda dengan Appel yang mengatakan alih kode itu terjadi antar bahasa, Hymes mengatakan alih kode itu bukan hanya terjadi antarbahasa, tetapi juga dapat terjadi antara ragam-ragam atau gaya-gaya yang terdapat dalam satu bahasa (Chaer. 2010: 108).

Selayaknya masyarakat tutur, dalam berkomunikasi dengan sesamanya, sering terjadi fenomena alih kode dan campur kode. Sebuah kode merupakan sistem komunikasi diantara dua atau lebih orang atau kelompok (Wardaugh, 2006:101). Holmes (1992:40) menjelaskan bahwa alih kode merupakan pergantian atau peralihan sebuah kode ke kode yang lain oleh penutur. Biasanya alih kode dilakukan dengan tujuan untuk menyesuaikan pendengar, topik, ranah, dan jarak sosial.

Orang-orang perlu memilih kode tertentu yang digunakan apabila berbicara. Selain itu, orang-orang juga memutuskan untuk mengganti kode yang digunakan dari satu kode ke kode yang lain atau untuk mencampurkan kode dalam tuturan yang singkat dan dengan demikian tercipta proses yang dinamakan alih kode (Wardaugh, 2006:101).

Dalam kaitannya dengan tuturan mahasiswa Aceh di Yogyakarta, fenomena alih kode dan campur kode banyak terjadi. Dalam berinteraksi, alih kode yang digunakan mahasiswa perantauan Aceh di Yogyakarta adalah alih kode dari Bahasa Indonesia. Alih kode ini biasa terjadi ketika mahasiswa Aceh bertemu orang yang sesama Aceh. Berikut contohnya:

\section{Contoh 1}

Konteks: Suatu hari saat kuliah umum di Grha Saba Pramana, A dan B mahasiswa baru asal Aceh. Keduanya mengikuti acara tersebut. Namun, di tengah percakapan datang $\mathrm{C}$ yang merupakan teman $\mathrm{B}$.

[1] B : Hai, kuliah di politik juga ya? 
[2] A : Iya,, Mas ini kuliah di politik juga?

[3] B : Iya, pantesan sering lihat. Asalnya darimana?

[4] A : Aceh.

[5] B : oo..awak aceh lagoe..lon awak aceh chit. Lon Popon. (oo..orang Aceh rupanya..Saya juga orang Aceh. Saya Popon)

[6] A :oo..lon Irda..(saya Irda)

[7] B :pat tinggai? (tinggal dimana?)

[8] A : di Jakal km. 4. Abang nyoe?

[9] B : lon di Palagan. Sewa rumoh ngon aneuk-aneuk Aceh chit (saya di Palagan. Sewa rumah bersama orang-orang Aceh juga)

[10] A : oo..

[11] B : Kal, sini....

[12] C : Hai, sudah lama?

[13] B : Sudah setengah jam lah...oya kenalkan ini teman dari Aceh.

[14] C : Oya, sudah nemu teman sekampung saja. Saya Haikal..

[15] A : Saya Irda.

Dst

Pada peristiwa tersebut, awalnya keduanya tidak saling kenal dan tidak tahu bahwa mereka berasal dari daerah yang sama. Jadi ketika awal berkenalan, mereka saling menggunakan bahasa Indonesia dalam ragam informal. Namun, ketika tahu bahwa mereka berasal dari satu daerah, maka mereka beralih kode dari Bahasa Indonesia ke Bahasa Aceh. Itu ditandai oleh kalimat [5] "oo..awak aceh lagoe..lon awak aceh chit. (o..orang aceh rupanya..saya orang aceh juga)". Selanjutnya A juga beralih kode, awalnya ia menyapa dengan sapaan "mas" pada baris [2] kemudian beralih kode menjadi "abang" pada baris [8] yang merupakan sapaan untuk lelaki yang lebih tua di Aceh.

Selanjutnya, fenomena alih kode tersebut kembali terjadi ketika ada selaan dari seorang teman bukan penutur Aceh. A dan B yang tadinya menggunakan bahasa Aceh untuk berkomunikasi, tiba-tiba tanpa ada sekepakatan yang tertulis, beralih berbahasa Indonesia ketika didatangi oleh $\mathrm{C}$, yang berbeda suku. Hal ini terdapat pada baris [11] $B \quad: \quad K a l, \quad$ sini.... Kemudian direspon oleh C [12] Hai, sudah lama?. Lalu percakapan mereka beralih ke Bahasa Indonesia dan kembali lancar.

Pembicaraan mengenai alih kode biasanya diikuti dengan campur kode. Kedua peristiwa yang lazim terjadi pada masyarakat bilingual ini mempunyai kesaamaan yang besar, hingga sulit di bedakan. Kesamaan yang ada antara alih kode dan campur kode adalah digunakannya dua bahasa atau lebih, atau dua 
varian dari sebuah bahasa dalam satu masyarakat tutur (Chaer, 2010: 114). Perbedaan keduanya sendiri ialah jika dalam alih kode setiap bahasa atau ragam bahasa yang digunakan itu masih memiliki fungsi masing-masing, dilakukan dengan sadar, dan sengaja dengan sebab-sebab tertentu. Sedangkan di dalam campur kode ada sebuah kode utama atau kode dasar yang digunakan dan memiliki fungsi dan keotonomiannya. Seorang penutur misalnya, yang dalam berbahasa Indonesia banyak menyelipkan serpihanserpihan bahasa daerahnya, bisa dikatakan telah melakukan campur kode. Akibatnya, akan muncul bahasa Indonesia yang kedaerah-daerahan.

Fenomena ini juga terjadi pada mahasiswa Aceh di Yogyakarta ketika berinteraksi dengan teman yang berasal dari daerah berbeda.

\section{Contoh 2:}

[1] A :Ke kumpul tugasnya kapan? (Kamu kumpul tugasnya kapan?)

[2] B : ya hari inilah, macam mana pula mau dikumpul besok. (Ya hari inilah, bagaimana pula dikumpul besok)

[3] A : oo..aku kek-kek mau kumpul besok aja..udah meuasap ulee (oo..aku sepertinya mau kumpul besok aja. Udah berasap kepala)

Pada contoh ini, A dan B berasal dari daerah yang berbeda. A berasal dari Aceh, sedangkan B berasal dari Batak. Percakapan yang terjadi dirumah tersebut, menjelaskan bahwa mereka memilih ragam bahasa Indonesia informal dalam kesehariannya. Dari percakapan tersebut terlihat, masing-masing berbicara bahasa Indonesia dengan kedaerah-daerahnya sendiri. Terdapat campur kode dari kalimat yang diujarkan A. Yang pertama, adalah penggunaan kata "ke" [1]. Ke adalah kata ganti kamu, yang sepengetahuan penulis hanya ada di Aceh; kedua adalah penggunaan "kek-kek" pada baris [3]. Kek-kek adalah bahasa yang sangat tidak formal, yang artinya seperti. Dalam hal ini, A masih sering mencampurkan bahasa daerahnya ke dalam bahasa Indonesia. Sehingga acapkali ia berbicara bahasa Indonesia yang keacehacehan. Hal tersebut juga terjadi pada frasa selanjutnya [3] "meuasap ulee". Pemilihan kata ini dilakukan A secara tidak sadar. Hal ini dikarenakan dua hal; pertama, A terbiasa dengan menggunakan Bahasa Daerah dikesehariannya sehingga serpihan Bahasa Daerah tetap ada meskipun sedang berbicara menggunakan bahasa lain; kedua, A kesulitan menemukan padanan kata "meuasap ulee" dalam Bahasa Indonesia.

Fenomena campur kode juga terjadi dengan mencampurkan bahasa Indonesia ketika mahasiswa Aceh sedang berbicara dengan sesamanya.

\section{Contoh 3}


[1] A : Na jak kuliah Cut? (Ada pergi kuliah Cut?)

[2] B : Hana kak. Karna gak ada kuliah, lon keuneuk jak u warnet le. Keuneuk download buku. (Tidak ada kak. Karena tidak ada kuliah hari ini. Saya mau pergi ke warnet dulu. Mau mengunduh buku)

Percakapan di atas, mengalami campur kode yang komplek. Penutur B tidak hanya menggunakan Bahasa Indoensia namun juga menggunakan Bahasa Asing (Bahasa Inggris). Campur kode pertama terjadi pada tataran klausa. Pertanyaan yang diajukan oleh A dalam Bahasa Aceh, kemudian dijawab dalam Bahasa Aceh pada awalnya, namun juga terdapat klausa dalam bahasa Indonesia "gak ada kuliah" [2]. Hal ini terjadi diduga karena kebiasaan B yang sering menggunakan Bahasa Indonesia dalam kesehariannya. Selanjutnya, penggunaan kata download [2] yang merupakan Bahasa Inggris juga dikarenakan kelaziman penggunaan kata asing ini di Indonesia. Masuknya pengaruh asing ke semua lini menyebabkan kata yang sebenarnya asing menjadi terlihat akrab bagi masyarakat.

\section{Faktor-Faktor Penyebab Terjadinya Alih Kode dan Campur Kode dalam Komunikasi Mahasiswa Perantauan Aceh.}

Fenomena kebahasaan ini tentu saja tidak serta-merta terjadi. tertu saja terdapat faktor-faktor penyebab terjadinya fenomena tersebut. Dalam berinteraksi, Hymes mengemukakan 16 komponen tutur yang harus diperhatikan yang kemudian ia menyingkatnya menjadi sebuah istilah dalam bahasa Inggris yaitu SPEAKING :

$\mathrm{S}=$ Situasi (act situation), mencakup latar dan suasana

$\mathrm{P}$ = Partisipan, mencakup penutur, pengirim, pendengar, dan penerima.

$\mathrm{E}=$ End (tujuan), mencakup bentuk pesan dan isi pesan.

$\mathrm{A}=$ Act Sequence (urutan tindak), mencakup bentuk pesan dan isi pesan

$\mathrm{K}=$ Key (kunci)

I = Instrumentalities (peranti, perabotan), mencakup saluran dan bentuk tutur.

$\mathrm{N}=\operatorname{Norms}$ (norma), mencakup norma interaksi dan norma interpretasi

$\mathrm{G}=$ Gendre (Sumarsono, 2007: 335)

Berdasarkan paparan Hymes dan contoh-contoh yang telah dipaparkan di atas, dapat dikaji bahwa faktor penyebab terjadinya alih kode dan campur kode pada komunitas perantauan aceh adalah: 
1) Penutur

Penutur kerap melakukan alih kode dan campur kode dengan maksud tujuan tertentu. Penutur tak jarang pula melakukan campur kode bahasa satu ke dalam bahasa yang lain karena kebiasaan berbahasa (seperti yang terlihat pada contoh 3) atau karena rasa ingin menonjolkan identitasnya (seperti pada contoh 1).

2) Lawan Tutur

Latar belakang lawan tutur juga mempengaruhi terjadinya alih kode dan campur kode. Seperti halnya pada contoh 1 di atas, kebahasaan yang sama menyebabkan penutur melakukan alih kode dari Bahasa Indonesia ke Bahasa Aceh.

3) Hadirnya penutur ketiga

Hadirnya penutur ketiga yang tidak memiliki kesamaan bahasa merupakan faktor yang menyebabkan alih kode sering terjadi. Hal ini bertujuan untuk memberi kenyamaan terhadap penutur ketiga tersebut (seperti dipaparkan pada contoh 1).

4) Modus Pembicaraan

Berdasarkan data-data yang ada dalam tulisan ini, modus pembicaraan yang digunakan adalah modus lisan dan ragam yang kerap digunakan adalah ragam informal. Sehingga, kecendrungan terjadi alih kode dan campur kode lebih besar.

5) Topik pembicaraan

Berdasarkan topik pembicaraan, dapat dijelaskan bahwa pada komunikasi mahasiswa perantauan aceh, topik-topik bersifat informal kerap menyebabkan terjadinya campur kode. Karena, penggunaan topik informal menyebabkan penutur bicara seenaknya sehingga campur kode mudah terjadi.

\section{Tujuan dan Fungsi Terjadinya Alih Kode dan Campur Kode pada Komunitas Mahasiswa Perantauan Aceh}

Penggunaan bahasa dalam peristiwa tutur tentu saja memiliki fungsi dan tujuan tertentu. Fungsi bahasa yang ada pada suatu peristiwa tutur didasari oleh tujuan dari komunikasi itu sendiri. Penutur menggunakan bahasa menurut fungsi yang dikehendakinya sesuai dengan tujuan, konteks, dan 
situasi komunikasi. Dalam rangka berinteraksi, mahasiswa Aceh melakukan alih kode dan campur kode dengan fungsi dan tujuan berikut:

1). Untuk mengakrabkan suasana.

Pesan yang disampaikan oleh penutur akan tersampaikan dengan baik kepada mitra tutur apabila hubungan emosional antara penutur dan mitra tutur terjalin dengan kedekatan dan keakraban. Untuk itu, kadangkala peristiwa alih kode dan campur kode dilakukan untuk mengakrabkan suasana. Salah satu contoh ialah yang telah dipaparkan sebelumnya pada contoh 1. Peristiwa bertemunya seseorang dengan yang lain yang belum dikenal sebelumnya, awalnya keduanya melakukan percakapan dengan menggunakan Bahasa Indonesia, setelah menyadari mereka berasal dari daerah yang sama kemudian dengan segera beralih ke bahasa daerahnya. Dalam konteks ini, bahasa daerah yang digunakan adalah Bahasa Aceh.

Sebagai contoh lain, percakapan seorang mahasiswa Aceh dengan dosennya yang juga berasal dari Aceh melalui media Whatsapp yang belum saling kenal sebelumnya. Berikut contohnya:

Contoh 4

[1] Mahasiswa : Assalamualaikum...Maaf mengganggu pak. Saya Cut Irna, mahasiswa bimbingan bapak.Untuk kelengkapan administrasi, saya membutuhkan KRS cetak. Namun, mata kuliah pada KRS online belum bapak setujui. Jika bapak berkenan dan berkesempatan, persetujuan tersebut akan sangat membantu saya. Terimakasih.

[2] Dosen : Baik Kak Cut. Sebentar lagi saya cek.

[3] Mahasiswa : Siap pak. Teurimong Geunaseh. (siap pak. Terimakasih) Sesaat kemudian..

[4] Dosen : Ka bereh beuh. (sudah beres ya)

[5] Mahasiswa : Get pak. Teurimong Geunaseh. (baik pak. Terimakasih)

Pada contoh di atas, pada awalnya mahasiswa memilih penggunaan Bahasa Indonesia sebagai alasan akademis untuk mengirim pesan kepada dosennya. Pada baris [2] terlihat campur kode yang dilakukan oleh dosen saat merespon pesan dari mahasiswa. Campur kode di sini yaitu penggunaan sapaan "kak", yang tidak lazim digunakan dalam konteks Jawa (baca: Yogyakarta). Sapaan yang digunakan di Jawa untuk wanita adalah Mbak. 
Selanjutnya juga terdapat alih kode pada [3] yang dilakukan oleh mahasiswa untuk membangun keakraban dengan dosen tersebut. Berikutnya, dosen juga melakukan alih kode ke Bahasa Aceh [4].

Pada contoh di atas, penutur melakukan alih kode dari Bahasa Indonesia ke Bahasa Aceh, juga melakukan campur kode dengan bahasa sisipan Bahasa Aceh pada bahasa dominan Bahasa Indonesia untuk menjalin keakraban.

2). Untuk membangkitkan rasa humor

Alih kode dan campur kode juga dilakukan dengan tujuan untuk membangkitkan rasa humor. Hal ini dilakukan mahasiswa Aceh dengan beralih kode ke Bahasa Aceh. Biasanya terjadi alih kode yang dilakukan dengan alih varian, alih ragam, atau alih gaya bicara dengan tujuan membangkitkan rasa humor untuk memecahkan kekakuan. Bahasa Aceh dipilih, karena pada situasi dan kondisi tertentu dalam bahasa yang lain tidak ditemukan padanan yang mempunyai sense yang sama.

\section{3). Untuk terlihat lebih bergengsi}

Berdasarkan data yang diperoleh, dalam berinteraksi di Yogyakarta, alih kode dan campur kode dengan pemakaian bahasa asing juga ditemui pada penggunaan bahasa oleh mahasiswa Aceh. pemakaian istilah asing ini dilakukan karena bahasa asing dianggap lebih berprestise sehingga penggunaannya akan terlihat lebih bergengsi. Ini sering ditemukan pada gaya bahasa remaja. Seperti contah data berikut:

[1] "Sorry lah ya, gak ada aku kek gitu"

[2] "Tugas chit tiep uroe. Jangan pikir kali. Let it flow aja"

4). Untuk menghormati lawan bicara

Alih kode dan campur kode oleh mahasiswa Aceh di perantauan juga dilakukan sebagai upaya untuk beradaptasi dengan lingkungan agar lawan bicara merasa dihargai. Untuk hal ini, kode yang digunakan adalah dengan mencampur kosakata Bahasa Jawa ketika berhadapan dengan lawan bicara yang berasal dari Jawa. Berikut contoh datanya:

Contoh 5

[1] A : Ngontrak di sini Mbak?

[2] B : nggeh bu.. baru semingguan bu. (iya bu. Baru semingguan bu)

Penggunaan kata 'nggeh' sebagai campur kode yang dilakukan B adalah bentuk penghormatan terhadap lawan bicara. Dalam hal ini, 
penutur ingin membesarkan lawan tuturnya dengan menggunakan bahasa yang dipakai oleh lawan tuturnya.

5). Untuk menuturkan hal rahasia

Alih kode dan campur kode banyak dilakukan oleh sesama perantauan yaitu ketika menuturkan hal-hal yang bersifat rahasia. Peristiwa tutur ini sering dilakukan oleh mahasiswa Aceh ketika berada di tempat umum. Agar orang lain tidak mengetahui apa yang mereka bicarakan. Salah satu contoh, ketika dua mahasiswa yang sama-sama berasal dari Aceh pergi ke pasar. Berikut contoh datanya:

Contoh 6

[1]Penjual : lima puluh ribu saja mbak, sudah murah.

[2] Mahasiswa 1: Gimana Fin? (menanyakan temannya)

[3] Mahasiswa 2: Terserah sih..tapi sang meuhai nyan. Meunyoe di bie lhee ploh ribee jeut. (tapi sepertinya mahal tu. Kalau dikasih 30 ribu boleh)

[4] Mahasiswa 1: iya..

Pada contoh tersebut, mahasiswa 2 melakukan alih kode dari Bahasa Indonesia ke Bahasa Aceh untuk menyatakan hal yang dirahasiakan dari penjual. Mahasiswa 2 memberi kode kepada mahasiswa 1 dalam Bahasa Aceh yang tidak dikuasai oleh penjual.

\section{KESIMPULAN}

Pada masyarakat tutur yang menggunakan lebih dari satu bahasa, kerap terjadi kontak bahasa. Salah satu dampak dari kontak bahasa adalah alih kode dan campur kode. Fenomena kebahasaan seperti alih kode dan campur kode juga terjadi pada masyarakat tutur mahasiswa Aceh di Yogyakarta.

Dalam pembahasan tentang alih kode dan campur kode dalam komunikasi mahasiswa perantauan Aceh, dapat disimpulkan bahwa: pertama, wujud alih kode dalam komunikasi mahasiswa Aceh di Yogyakarta meliputi alih kode dari Bahasa Aceh ke Bahasa Indonesia dan alih kode dari Bahasa Indonesia ke Bahasa Aceh; kedua, wujud campur kode berupa penyisipan kata, frase, dan klausa; ketiga, faktor-faktor penyebab terjadinya alih kode dan campur kode adalah penutur, lawan tutur, hadirnya penutur ketiga, modus pembicaraan dan topik pembahasan; keempat, tujuan dan fungsi terjadinya alih kode dan campur kode pada komunikasi mahasiswa perantauan Aceh adalah untuk mengakrabkan suasana, untuk membangkitkan rasa humor, untuk 
terlihat bergengsi, untuk menghormati lawan bicara dan untuk menuturkan hal rahasia.

\section{DAFTAR PUSTAKA}

Chaer, Abdul dan Leonie Agustina. 2010. Sosiolinguistik: Perkenalan Awal. Jakarta: Rineka Cipta.

Holmes, Janet. 1992. An Introduction to Sociolinguistics. London and New York: Longman.

Indrastuti, Novi.S.K. 1997. Alih Kode dan Campur Kode dalam Siaran Radio: Kajian Sosiolinguistik. Humaniora V, 38-45. https://jurnal.ugm.ac.id/jurnal-humaniora/article/view/1878/1685

Kridalaksana, Harimurti. 1982. Pengantar Soisiolinguistik. Baandung : Angkasa

Nababan, P.W.J. 1986. Sosiolinguistik: Suatu Pengantar . Jakarta: Gramedia. Naiditch, L. 2000. Code-Switching And-Mixing in Russian-Hebrew Bilinguals. Studies in Slavic And General Linguistics, 28, 277-282. Retrieved from http://www.Jstor.org/Stable/40997171

Poedjosoedarmo, Soepomo. 1989. Cara Menyusun Karya Ilmiah. Brunei Darussalam: Universiti Brunei Darussalam. . 1989. Kode dan Alih Kode dalam Widyaparma No.15. Yogyakarta: Balai Penelitian Bahasa.

Sudaryanto. 1993. Metode dan Aneka Teknik Analisis Bahasa. Yogyakarta: Duta Wacana University Press

Sumarsono. 2007. Sosiolinguistik. Yogyakarta: Sabda dan Pustaka Pelajar.

Thomason, Sarah G. 2001. Language Contact: An Introduction. Edinburgh \& Washington, DC: Edinburgh University Press \& Georgetown University Press.

Wardaugh, Ronald. 2006. An Introduction to Socioloinguistics. USA: Blackwell Publishing. 